\title{
Experimental furcal perforation treated with mineral trioxide aggregate plus selenium: immune response
}

\section{Marcela Carvalho ESPALADORI (a) Kamilla Faria MACIEL(a) Luciana Carla Neves de BRITO(b) Toshihisa KAWAI(c) Leda Quércia VIEIRA(d) Antônio Paulino RIBEIRO SOBRINHO(a)}

(a) Universidade Federal de Minas Gerais UFMG, School of Dentistry, Departament of Operative Dentistry, Belo Horizonte, MG, Brazil.

(b) Universidade de Itaúna, School of Dentistry, Itaúna, MG, Brazil.

(c)The Forsyth Institute, Department of Immunology, Boston, MA, USA.

(d) Universidade Federal de Minas Gerais UFMG, Institute of Biological Sciences, Departament of Biochemistry and Immunology, Belo Horizonte, MG, Brazil.

Declaration of Interest: The authors certify that they have no commercial or associative interest that represents a conflict of interest in connection with the manuscript.

\section{Corresponding Author:}

Antônio Paulino Ribeiro Sobrinho

E-mail: sobrinho.bhz@gmail.com

https://doi.org/10.1590/1807-3107bor-2018.vol32.0103

Submitted: June 26, 2017

Accepted for publication: August 01, 2018

Last revision: August 23, 2018
Abstract: The aim of this study is to evaluate the expression of cytokines in response to mineral trioxide aggregate (MTA) plus selenium in germ-free mice with experimental furcal perforation. The first left maxillary molar was opened, and the furcal area was perforated and treated with post-MTA-Se (experimental group). The same surgical intervention was performed for the maxillary right first molar, which was treated with MTA (control group). Fifteen mice were sacrificed 7, 14, and 21 days after furcal perforation, and periapical tissue samples were collected. The mRNA expression levels of the cytokines TGF- $\beta$, TNF- $\alpha$, IFN- $\gamma$, HPRT, IL-10, IL-4, RANK, RANKL, IL-1, and IL-17 were assessed by using real-time polymerase chain reaction. In the experimental group, at 21-days post-MTA-Se sealing, the mRNA levels of TNF- $\alpha$ and IL-10 were upregulated compared with those in the control group $(\mathrm{p}<0.05)$. Futher assessment revealed basal mRNA expression levels of IL-1 $\alpha$, IFN- $\gamma$, RANK, RANKL, IL-17A, IL-4, and TGF- $\beta$, over long experimental times, in both the experimental and control groups ( $p>0.05)$. In conclusion, MTA+Se sealing favoured increased expression of IL-10 and TNF- $\alpha$ at later time points (day 21).

Keywords: Selenium; Cytokines; Immunophenotyping; Models, Animal.

\section{Introduction}

Furcal perforation is mechanically driven or pathologically induced communication between root canals and supportive dental tissues. ${ }^{1}$ Perforations usually result from resorption or, caries or may be produced iatrogenically. ${ }^{1,2}$ Such perforations are the second most common cause of failed endodontic treatments, with serious clinical consequences. ${ }^{1}$ Treatment consists of using a biocompatible material to seal the cavity and aims to prevent bacterial invasion, inflammation dissemination, and periradicular bone destruction. ${ }^{1}$

Periradicular bone destruction around the perforation depends on the balance between proinflammatory (type 1) and anti-inflammatory (type 2) cytokines., ${ }^{3,45}$ Proinflammatory cytokines, such as IFN- $\gamma$, TNF- $\alpha$, and RANKL, play a key role in lesion progression. IFN- $\gamma$ and TNF- $\alpha$ act on bone resorption by inducing the release of RANKL, which helps to differentiates and activates osteoclasts. ${ }^{4,6}$ Conversely, 
the production of cytokines such as IL-4, IL-10, and IL-13 by lymphocytes inhibits bone resorption and initiates tissue repair.?

Mineral trioxide aggregate (MTA) is the main material used to seal root canal perforations given its biocompatibility, insolubility, and sealing ability, among other properties. ${ }^{2,8}$ It has been demonstrated that MTA affects neither phagocytosis nor the ability of macrophages (M1 and M2) to eliminate microorganisms. ${ }^{9}$ Additionally, an evaluation of its effect on the adaptive immune response revealed that it did not interfere with the expression of IL-10, TNF- $\alpha$, or RANKL by memory T cells. ${ }^{10}$

Selenium (Se) is being used in several medical applications, including cancer treatment, as a bacterial growth inhibitor on instruments or biological prostheses, in bone metabolism, and as an immune system booster. ${ }^{11,12}$ Se may slow bone growth by changing bone metabolism. ${ }^{13}$ The blood concentration of Se is inversely related to the rate of bone renewal and positively associated with low bone mineral density in humans. ${ }^{14}$ Low intake of Se correlates with a high risk of bone diseases. ${ }^{15,16}$

Se is an essential mineral present in selenocysteine, an amino acid involved in various biological activities, such as antioxidant defence, cell division and differentiation, and mainly participates in maintaining the proper function of the immune system. ${ }^{17}$ The lack of Se leads to a reduction in mature T-cell reserves and the activation of faulty T-cells. 18,19,20,21,22

Several studies have demonstrated that MTA presents excellent properties to treat root canal perforations. With that in mind, our experiment involved supplementing MTA with an essential mineral such as Se, which is capable of inhibiting bacterial growth and stimulating the immune system and bone renewal, as a way to enhance the properties of MTA. In the present study, experimental furcal perforations were generated in mandibular molars of germ-free mice. Perforations were sealed with MTA or MTA plus Se in the form of sodium selenite. Animals were longitudinally sacrificed, and the expression of cytokines, namely TGF- $\beta$, TNF- $\alpha$, IFN- $\gamma$, IL-10, IL-4, RANK, RANKL, IL-1, IL-17, and HPRT, was evaluated by using real-time polymerase chain reaction (RT-PCR).

\section{Methodology}

\section{Animals}

Fifteen germ-free mice of both sexes aged between 4 and 8 weeks, were used in this experiment (Swiss/NIH, ICB, Universidade Federal de Minas Gerais, Belo Horizonte, Brazil). All animals were maintained in Trexler isolators (Madison, USA) and transferred to micro-isolators (UNO, Roestvastaal BV, Zevenaar, New Zealand) to perform the procedures. All procedures were performed under sterile conditions in laminar flow cabinets (Veco, Campinas, Brazil). The animals were fed ad libitum. The present study was approved by the Ethics Committee for the Use of Animals in Research (67/2014 CEUA/UFMG).

\section{Experimental furcal perforation}

The procedures were performed as described previously. ${ }^{23,24,25}$ In brief, before any procedure, animals were anaesthetized intraperitoneally with $100 \mathrm{mg} / \mathrm{kg}$ ketamine hydrochloride (Dopalen, Division Vetbrands Animal Health, Jacareí, Brazil) and $10 \mathrm{mg} / \mathrm{kg}$ xylazine (Anasedan, Agribands do Brasil LTDA, Paulínia, Brazil). Pulp chambers of the first upper molars were accessed with a $1 / 2$ sterile carbide drill (KG Sorensen, Barueri, Brazil) attached to a controlled speed motor (Driller, São Paulo, Brazil), under endodontic operative microscopy (Alliance, São Paulo, Brazil). Furcal perforation was performed using $1 / 4$ sterile carbide drills, perpendicular to the furcal zone and parallel to the long axis of the tooth (Figure 1 shows a schematic representation). Perforation cavities of the right molars (control) were sealed with MTA Bios (Ângelus, Londrina, Paraná, Brazil), while those of the left molars (experimental) were sealed with MTA plus Se. All clinical crowns were sealed with Coltosoll®) (Coltène/Whaledent AG Altstätten, Suisse).

\section{MTA manipulation}

MTA was prepared following the manufacturers' instructions under sterile conditions. Subsequently, $1-\mu \mathrm{M}$ sodium selenite solution was incorporated into MTA. To define an adequate Se concentration, macrophages $\left(1 \times 10^{5}\right.$ cells $\left.\mathrm{mL}^{-1}\right)$ isolated from Swiss $/ \mathrm{NIH}$ 


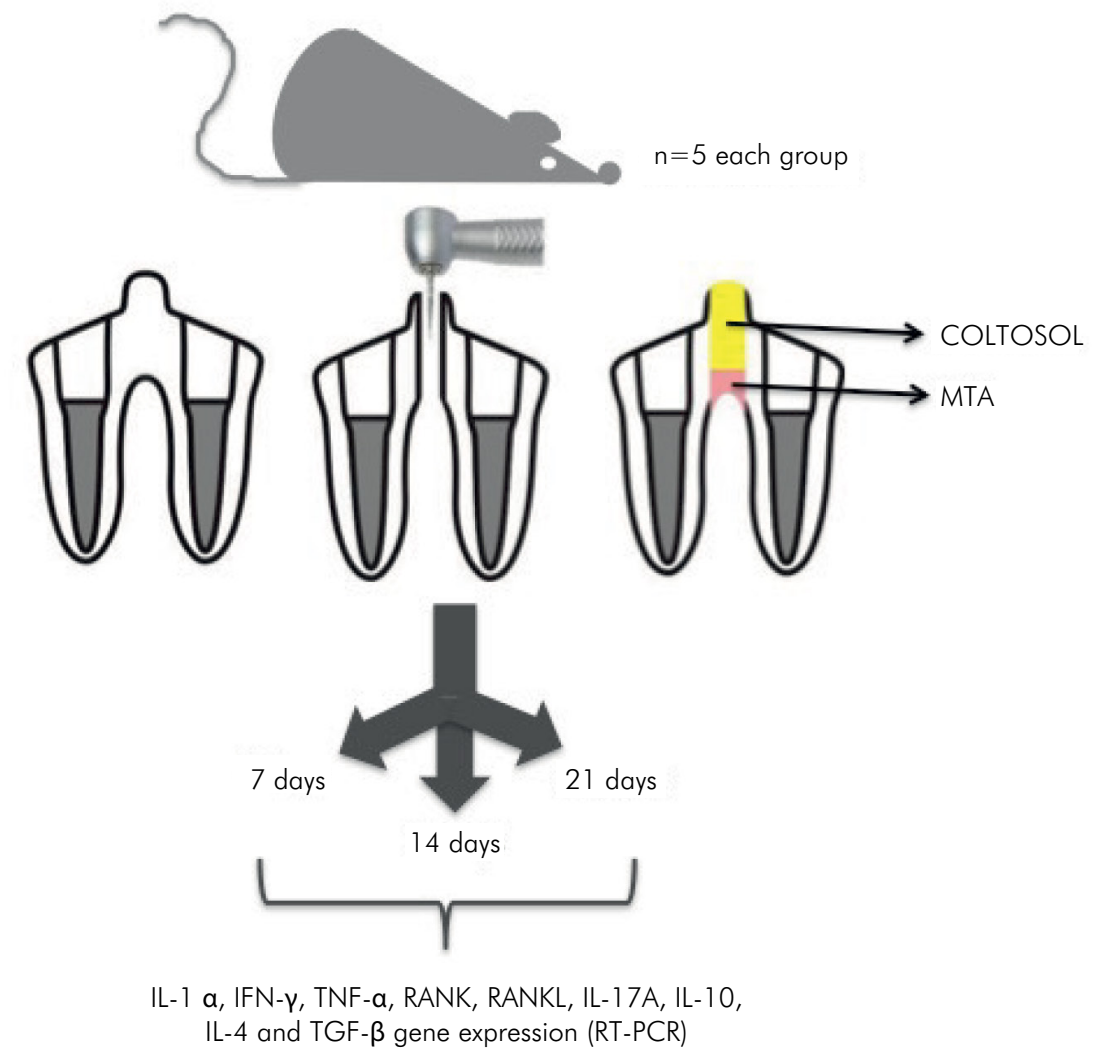

Figure 1. Germ free mouse model of experimental furcation perforation: schematic representation of the treatment protocol.

mice were cultured in $1 \mathrm{~mL}$ of medium in 24-well culture plates (Nunclon; Nalge Nunc International, Naperville, USA) in the presence of several dilutions of Se. At Se concentrations $\leq 10 \mu \mathrm{M}$, the viability, adherence and phagocytosis ability of macrophages were not modified (data not shown).

\section{Preparation of the tissue samples}

Animals were sacrificed at 7, 14, and 21 days after perforation $(n=5)$. Periradicular tissues adjacent to furcal perforations were aseptically removed and frozen at $-70^{\circ} \mathrm{C}$. mRNA was isolated by TriZol (Gibco BRL Laboratories, Grand Island, USA), followed by the addition of chloroform and centrifugation at $12,000 \mathrm{~g} g$ and $4^{\circ} \mathrm{C}$ for $10 \mathrm{~min}$. The aqueous phase was collected, and isopropanol was added to precipitate RNA, followed by centrifugation at $12,000^{\prime} g$ and $4^{\circ} \mathrm{C}$ for $10 \mathrm{~min}$. mRNA was washed with $75 \%$ ethanol, dried, dissolved in RNAase-free water, and incubated at $55^{\circ} \mathrm{C}$ for $10 \mathrm{~min} .{ }^{24,25}$

\section{Real-time PCR}

Complementary DNA was synthesized by reverse transcription using $2 \mu \mathrm{g}$ of RNA. ${ }^{24}$ The standard PCR conditions were as follows: a holding stage of $95^{\circ} \mathrm{C}$ for $10 \mathrm{~min}$; a cycling stage with 40 cycles of $95^{\circ} \mathrm{C}$ for $15 \mathrm{~s}$ and $60^{\circ} \mathrm{C}$ for $1 \mathrm{~min}$; and a melting curve stage of $95^{\circ} \mathrm{C}$ for $15 \mathrm{~s}, 60^{\circ} \mathrm{C}$ for $1 \mathrm{~min}$ and $95^{\circ} \mathrm{C}$ for $15 \mathrm{~s}$. The primer sequences used for the analysis of INF$\gamma$, TNF- $\alpha$, IL-1 $\beta$, IL-17, IL-10, TGF- $\beta$, IL-4, RANK, and RANKL mRNA expression by quantitative real-time PCR are shown in Table. The primer sequences were designed by using Primer Express software (Applied Biosystems, Foster City, CA, USA) based on the nucleotide sequences available in GenBank. Real-time PCR was performed using the Step One Real-time PCR System (Applied Biosystem). In addition, the Sybr Green detection system (Applied Biosystems) was used to assay primer amplification. The housekeeping gene hypoxanthine phosphoribosyltransferase (HPRT) was used to normalise mRNA expression levels. All 
Table. Primer sequences used in PCR reactions.

\begin{tabular}{|c|c|c|c|}
\hline Gene & Sense and antisense & Length $(b p)^{*}$ & NCBI/GeneBank reference \\
\hline \multirow{2}{*}{ HPRT } & FW: GTTGGATACAGGCCAGACTTTGTT & \multirow{2}{*}{163} & \multirow{2}{*}{$\mathrm{JO} 0423.4$} \\
\hline & RV: GATTCAACTTGCGCTCATCTTAGG & & \\
\hline \multirow{2}{*}{ TNF- $\alpha$} & FW: ATCTTCTCAAAATTCGAGTGACCA & \multirow{2}{*}{173} & \multirow{2}{*}{ AB062426.1 } \\
\hline & RV: TGGAGTAGACAAGGTACAACCC & & \\
\hline \multirow{2}{*}{ TGF- $\beta$} & FW: TGACGTCACTGGAGTTGTACG & \multirow{2}{*}{170} & \multirow{2}{*}{ AY340221.1 } \\
\hline & RV: GGTTCATGTCATGGATGGTGC & & \\
\hline \multirow{2}{*}{ RANKL } & FW: CATCCCATCGGGTTCCCATAA & \multirow{2}{*}{100} & \multirow{2}{*}{ AF019048.1 } \\
\hline & RV: CCTTAGTTTTCCGTTGCTTAACGAC & & \\
\hline \multirow{2}{*}{ RANK } & FW: TGCTGGCATGGTGATGGA & \multirow{2}{*}{78} & \multirow{2}{*}{ AF019046.1 } \\
\hline & RV: GAATGATGCCAGGTGGTAGGA & & \\
\hline \multirow{2}{*}{ IL-4 } & FW: ACAGGAGAAGGGACGCCAT & \multirow{2}{*}{95} & \multirow{2}{*}{ NM_021283.2 } \\
\hline & RV: GAAGCCCTACAGACGAGCTCA & & \\
\hline \multirow{2}{*}{ IL-17A } & FW: TGAGCTTCCCAGATCACAGA & \multirow{2}{*}{101} & \multirow{2}{*}{ NM_010552.3 } \\
\hline & RV: TGCAGAACGCCCTCAGACTA & & \\
\hline \multirow{2}{*}{ IL-10 } & FW: GGTTGCCAAGCCTTATCGGA & \multirow{2}{*}{191} & \multirow{2}{*}{ NM_01058.2 } \\
\hline & RV: ACCTGCTCCACTGCCTTGCT & & \\
\hline \multirow{2}{*}{$\mathrm{IFN}-\gamma$} & FW: CAAGTGGCATAGATGTGGAAGAA & \multirow{2}{*}{91} & \multirow{2}{*}{ NM_008337.4 } \\
\hline & RV: TGGCTCTGCAGGATTTTCATG & & \\
\hline \multirow{2}{*}{ IL-1 $\beta$} & FW: CAACCAACAAGTGATATTCTCCATG & \multirow{2}{*}{152} & \multirow{2}{*}{ NM_008361.4 } \\
\hline & RV: GATCCACACTCCCAGCTGCA & & \\
\hline \multirow{2}{*}{ IL-6 } & FW: TTCCATCCAAGTTGCCTTCTTG & \multirow{2}{*}{102} & \multirow{2}{*}{ M24221.1 } \\
\hline & RV: TTGGGAGTGGTATCCTCTGTGA & & \\
\hline
\end{tabular}

FW: forward primer; RV: reverse primer. *Amplicon length in base pairs.

samples were run in duplicate in a $20 \mu \mathrm{L}$ reaction volume with $1 \mu \mathrm{g}$ of cDNA. Sequence Detection Software version 2.0 (Applied Biosystems) was used to analyse data after amplification. The results were obtained as threshold cycle $(\mathrm{Ct})$ values. Expression levels were calculated using the comparative $\mathrm{C}(\mathrm{T})$ method. ${ }^{26}$ The $\mathrm{Ct}$ values are expressed as the mean of two independent measurements, and the mRNA expression levels for all samples are expressed as the ratio between the expression of the gene of interest and the expression of HPRT..$^{24,26,27}$

\section{Statistical analysis}

Statistical analysis was performed by the normality test (Shapiro-Wilk test) and homogeneity test (Levene test). Subsequently, analysis of variance (for data with a normal distribution) and the Kruskal-Wallis test (for data with a non-normal distribution). Followed by a post hoc test (with Bonferroni correction), were used for analysing more than two independent variables. For analysing two independent variables, Student's t-test (for a normal distribution) and the KolmogorovSmirnov $Z$ test (for non-normal distribution) were used. The level of significance was $95 \%$, and a p-value $<0.05$ was considered significant.

\section{Results}

The expression of cytokinesIL-1 $\alpha$, IFN- $\gamma$, TNF- $\alpha$, RANK, RANKL, IL-17A, IL-10, IL-4, and TGF- $\beta$ was assessed by using real-time PCR and normalised to the HPRT gene. At all time points evaluated and in both groups, basal expression of IL- $1 \alpha$, IFN- $\gamma$, RANK, RANKL, IL-17A, IL-4, and TGF- $\beta$ was observed $(p>0.05$; data not shown). At 21 days after sealing the perforation with MTA/Se, TNF- $\alpha$ expression was significantly 


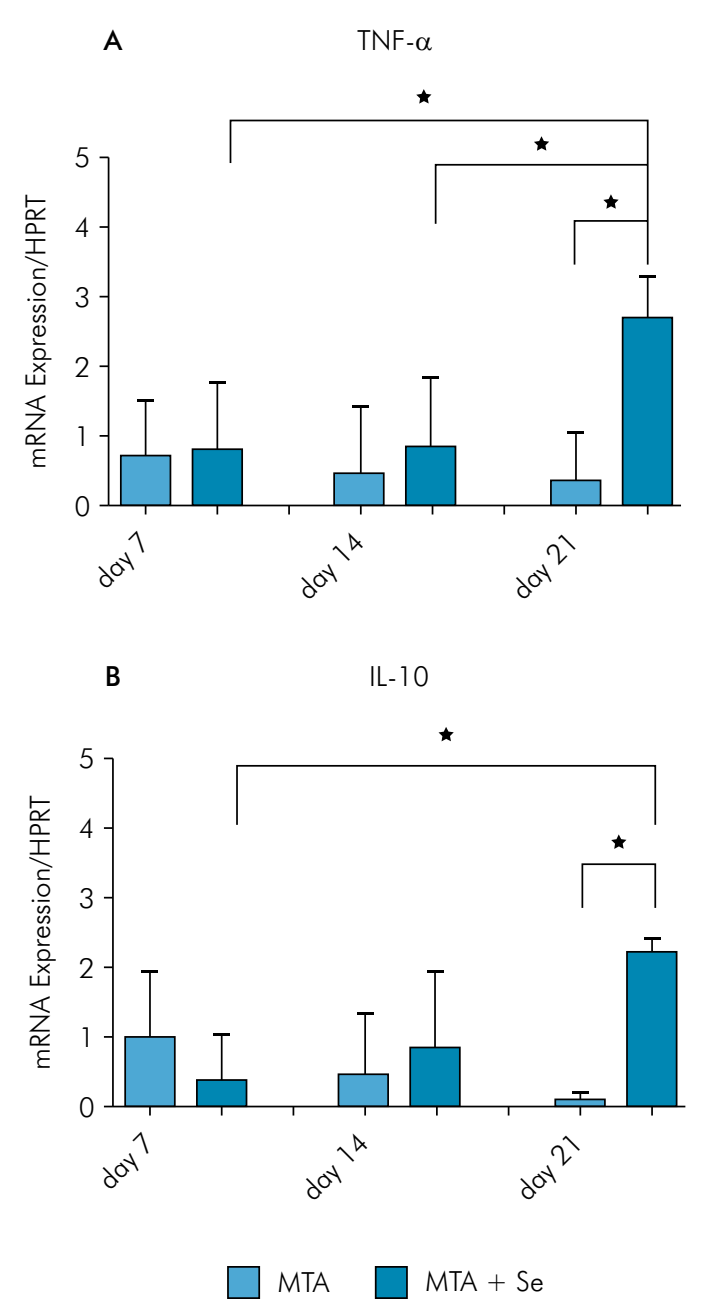

Figure 2. mRNA expression of TNF- $\alpha$ and IL-10 in the furcal area of germ free mouse subjected to experimental furcal perforation sealed with MTA or MTA+Se at 21 days. The expression levels were determined by real time PCR and quantified by comparison with a housekeeping gene (HPRT). Bars represent the average of five experiments performed in duplicate, while horizontal lines represent the standard error.

higher compared to that after sealing with MTA alone (control group) at the same time (Figure 2). Additionally, TNF- $\alpha$ expression at 21 days was significantly higher than that at 7 and 14 days in the experimental group $(p<0.05)$. IL-10 expression presented a similar profile, where it was significantly higher at 21 days in the group treated with MTA/Se, compared to the control group treated with MTA $(\mathrm{p}<0.05)$. In the experimental group (MTA/Se), IL-10 expression was significantly higher at day 21 than at day $7(\mathrm{p}<0.05$; Figure 2$)$.

\section{Discussion}

Gnotobiotic animals are good models for the study of dental materials in vivo.

These animal models are beneficial for determining the real effects of dental materials since the absence of indigenous bacterial microbiota allows for analysis of the relationship between their properties and the host immune system free from bacterial interference. ${ }^{3}$ In this study, a well tested experimental furcal perforation was used. ${ }^{25}$

Furcal perforation is mechanical or pathological communication between the root canals and the supportive dental tissues. ${ }^{1}$ After tooth perforation, a biocompatible material is chosen to seal the cavity to avoid bacterial invasion and periradicular inflammation. ${ }^{28,29}$ In this regard, MTA has been shown to have excellent potential for endodontic applications. ${ }^{2,8}$ In this study, the expression of cytokines was longitudinally assayed to associate the specific genotype-first response to the biocompatible material used to seal the furcal perforation. This approach can prevent initial phenotypic bias and can allow for the identification of cytokine genes that significantly contribute to the immune response. ${ }^{30}$

In agreement with previous studies ${ }^{9,31}$ MTA induces a host-protective proinflammatory response, increasing the expression of proinflammatory cytokines in the initial phase after its placement (7 to 14 days) and favouring the expression of immunoregulatory cytokines in the late phase (21 days). In this study, with the intention of potentiating the immune response, inorganic Se was added to MTA to affect, the proliferation, differentiation, and function of immunological cells. $18,19,20,21,22,23,32$

The expression of the proinflammatory cytokines IL-1 $\alpha$, IFN- $\gamma$, RANK, RANKL, and IL-17 and the antiinflammatory cytokines TGF- $\beta$ and IL- 4 was at basal levels at 7, 14, and 21 days in the control and experimental groups. Similar to the outcomes demonstrated, MTA/Se does not interfere with IFN- $\gamma$ expression. ${ }^{24}$ Conversely, we reported an increase in TNF- $\alpha$, IL- 4 , and RANKL expression by macrophages in vitro on days 7 and 14, followed by a decrease on day $21 .{ }^{9}$ 
Some inflammatory cytokines play essential roles in the innate immune response. IL-1 and TNF- $\alpha$ induce the expressions of adhesion molecules by endothelial cells, increasing the trafficking of phagocytes during inflammation. ${ }^{23,31,32,33,34}$ Moreover, these cytokines induce pulpal inflammation ${ }^{23}$ and bone resorption in inflamed periradicular tissues. ${ }^{33}$ In this study, when comparing the expression of TNF- $\alpha$ between the control and experimental groups, a significant increase in its expression was observed on day 21 in the experimental group. On the other hand, MTA did not interfere with the production of TNF- $\alpha$ by M1 and M2 macrophages. ${ }^{1}$ However, an increase in the production of TNF- $\alpha$ by T-memory lymphocytes was observed on days 7 and 14, followed by a reduction on day 21 in the presence of MTA. ${ }^{35}$ Previously, it was demonstrated that macrophages stimulated with lipopolysaccharide in Se-free cultures secrete significantly lower levels of TNF- $\alpha$, IL-1 $\beta$, and IL-6 compared to cultures stimulated with LPS in the presence of Se. ${ }^{36}$ Accordingly, in this study, the increase in TNF- $\alpha$ expression on day 21 was found only in perforations treated with MTA/Se. Moreover, TNF- $\alpha$ has numerous biological activities, including the ability to stimulate neoangiogenesis. ${ }^{37}$ This finding suggests that the increased expression of TNF- $\alpha$ in the perforations treated with MTA/Se may stimulate the initiation and progression of angioproliferative processes that will culminate in furcal perforation healing, as demonstrated elsewhere. ${ }^{38}$

IL-10 is a regulatory cytokine that inhibits proinflammatory responses. ${ }^{39}$ IL-4 and IL-10 expression is generally reduced in the initial phase and increased in the late chronic phase of the immune response..$^{40}$ Similar to what has been

\section{References}

\footnotetext{
1. Hamad HA, Tordik PA, McClanahan SB. Furcation perforation repair comparing gray and white MTA: a dye extraction study. J Endod. 2006 Apr;32(4):337-40. https://doi.org/10.1016/i.joen.2005.10.002

2. Yildirim T, Gençoğlu N, Firat I, Perk C, Guzel O.

Histologic study of furcation perforations treated with

MTA or Super EBA in dogs' teeth. Oral Surg Oral Med
}

reported in the literature, a significant increase in IL-10 production was detected on day 21 in the experimental group compared to the control group in this study. ${ }^{9,23,33}$ This higher Se-related IL-10 expression modulates the proinflammatory response that occur during perforation, which is helpful for the perforation healing process, as previously demonstrated. ${ }^{41,42}$ Appropriate intake of Se contributes to the balance of the differentiation of Th1 and Th2 lymphocytes, thus promoting a balance between the production of proinflammatory and anti-inflammatory cytokines. ${ }^{36}$

\section{Conclusion}

The results of this study support our hypothesis that Se may indeed improve the ability of MTA to treat root canal perforation. Se not only maintained the same cytokine profile induced by MTA but also led to higher late expression levels of TNF- $\alpha$ and IL-10. TNF- $\alpha$ stimulates angioproliferative processes that culminate in furcal perforation healing. IL-10 inhibits proinflammatory responses and stimulates the beginning of wound healing in a given site. Nonetheless, further experimental studies should be performed to demonstrate whether the addition of Se to MTA definitively contributes to the improvement of its biological properties.

\section{Acknowledgements}

This work was supported by FAPEMIG, CAPES, and CNPq. The authors wish to thank the postgraduate programme at the School of Dentistry of UFMG. APRS, LCNB and LQV are CNPq fellows. The authors declare no potential conflicts of interest with respect to the authorship and/or publication of this article.

\footnotetext{
Oral Pathol Oral Radiol Endod. 2005 Jul;100(1):120-4. https://doi.org/10.1016/j.tripleo.2004.09.017

3. Ribeiro Sobrinho AP, Maltos SMM, Farias LM, Carvalho MA, Nicoli JR,

Uzeda $M$ et al. Cytokine production in response to endodontic infection in germ-free mice. Oral Microbiol Immunol. 2002 Dec;17(6):344-53. https://doi.org/10.1034/i.1399-302X.2002.170603.x
} 
4. Čolíc, M, Gazivoda D, Vucevic D, Sasa V, Rudolf R, Lukic A. Proinflammatory and immunoregulatory mechanisms in periapical lesions. Mol Immunol. 2009 Nov;47(1):101-13. https://doi.org/10.1016/i.molimm.2009.01.011

5. Teixeira-Salum TB, Rodrigues DB, Gervásio AM, Souza CJ, Rodrigues Junior V, Loyola AM. Distinct Th1, Th2 and Treg cytokines balance in chronic periapical granulomas and radicular cysts. J Oral Pathol Med. 2010 Mar;39(3):250-6. https://doi.org/10.1111/j.1600-0714.2009.00863.x

6. Boyle WJ, Simonet WS, Lacey DL. Osteoclast differentiation and activation. Nature. 2003 May;423(6937):337-42. https://doi.org/10.1038/nature01658

7. Stashenko P, Wang CY, Tani-Ishii N, Yu SM. Pathogenesis of induced rat periapical lesions. Oral Surg Oral Med Oral Pathol. 1994 Oct;78(4):494-502. https://doi.org/10.1016/0030-4220(94)90044-2

8. Main C, Mirzayan N, Shabahang S, Torabinejad M. Repair of root perforations using mineral trioxide aggregate: a long-term study. J Endod. 2004 Feb;30(2):80-3. https://doi.org/10.1097/00004770-200402000-00004

9. Rezende TMB, Vargas DL, Cardoso FP, Ribeiro Sobrinho AP, Vieira $L Q$. Effect of mineral trioxide aggregate on cytokine production by peritoneal macrophages. Int Endod J. 2005 Dec;38(12):896903. https://doi.org/10.1111/j.1365-2591.2005.01036.x

10. Rezende TMB, Vieira LQ, Cardoso FP, Oliveira RR, Mendes STO, Jorge MLR et al. The effect of mineral trioxide aggregate on phagocytic activity and production of reactive oxygen, nitrogen species and arginase activity by $\mathrm{Ml}$ and M2 macrophages. Int Endod J. 2007 Aug;40(8):603-11. https://doi.org/10.1111/j.1365-2591.2007.01255.x

11. Mehdi Y, Hornick JL, Istasse L, Dufrasne I. Selenium in the environment, metabolism and involvement in body functions. Molecules. 2013 Mar;18(3):3292-311. https://doi.org/10.3390/molecules18033292

12. Zeng H, Cao JJ, Combs GF Jr. Selenium in bone health: roles in antioxidant protection and cell proliferation. Nutrients. 2013 Jan;5(1):97-110. https://doi.org/10.3390/nu5010097

13. Moreno-Reyes R, Egrise D, Nève J, Pasteels JL, Schoutens A. Selenium deficiency-induced growth retardation is associated with an impaired bone metabolism and osteopenia. J Bone Miner Res. 2001 Aug;16(8):1556-63. https://doi.org/10.1359/jbmr.2001.16.8.1556

14. Hoeg A, Gogakos A, Murphy E, Mueller S, Köhrle J, Reid $D M$ et al. Bone turnover and bone mineral density are independently related to selenium status in healthy euthyroid postmenopausal women. J Clin Endocrinol Metab. 2012 Nov;97(11):4061-70. https://doi.org/10.1210/jc.2012-2121

15. Johnson CC, Fordyce FM, Rayman MP. Symposium on 'geographical and geological influences on nutrition': factors controlling the distribution of selenium in the environment and their impact on health and nutrition. Procs Nutr Soc. 2010 Feb; 69(1):119-32. https://doi.org/10.1017/S0029665109991807
16. Zhang J, Munger RG, West NA, Cutler DR, Wengreen $\mathrm{HJ}$, Corcoran CD. Antioxidant intake and risk of osteoporotic hip fracture in Utah: an effect modified by smoking status. Am J Epidemiol. 2006 Jan;163(1):9-17. https://doi.org/10.1093/aje/kwj005

17. Brown KM, Arthur JR. Selenium, selenoproteins and human health: a review. Public Health Nutr. 2001 Apr;4(2b 2B):5939. https://doi.org/10.1079/PHN2001143

18. Shrimali RK, Irons RD, Carlson BA, Sano Y, Gladyshev VN, Park $J M$ et al. Selenoproteins mediate $T$ cell immunity through an antioxidant mechanism. J Biol Chem. 2008 Jul;283(29):201815. https://doi.org/10.1074/jbc.M802559200

19. Behne D, Wolters W. Distribution of selenium and glutathione peroxidase in the rat. J Trace Elem Med Biol. 2009;23(4):25864. https://doi.org/10.1016/i.jtemb.2009.05.001

20. Gromer S, Eubel JK, Lee BL, Jacob J. Human selenoproteins at a glance. Cell Mol Life Sci. 2005 Nov;62(21):2414-37. https://doi.org/10.1007/s00018-005-5143-y

21. Bhaskaram P. Micronutrient malnutrition, infection, and immunity: an overview. Nutr Rev. 2002 May;60(5 Pł 2 suppl_5):S40-5. https://doi.org/10.1301/00296640260130722

22. Arthur JR, McKenzie RC, Beckett GJ. Selenium in the immune system. J Nutr. 2003 May;133(5 Suppl 1):1457S-9S. https://doi.org/10.1093/jn/133.5.1457S

23. Yasuda Y, Ogawa M, Arakawa T, Kadowaki T, Saito $T$. The effect of mineral trioxide aggregate on the mineralization ability of rat dental pulp cells: an in vitro study. J Endod. 2008 Sep;34(9):1057-60. https://doi.org/10.1016/i.joen.2008.06.007

24. Barbosa Silva MJ, Vieira LQ, Ribeiro Sobrinho AP. The effects of mineral trioxide aggregates on cytokine production by mouse pulp tissue. Oral Surg Oral Med Oral Pathol Oral Radiol Endod. 2008 May;105(5):e70-6. https://doi.org/10.1016/j.tripleo.2008.01.025

25. Lara VP, Cardoso FP, Brito LC, Vieira LQ, Ribeiro Sobrinho AP, Rezende TM. Experimental furcal perforation treated with MTA : analysis of the cytokine expression. Braz Dent J. 2015 Jul-Aug;26(4):337-41. https://doi.org/10.1590/0103-6440201300006

26. Schmittgen TD, Livak KJ. Analyzing real-time PCR data by the comparative C(T) method. Nat Protoc. 2008;3(6):1101-8. https://doi.org/10.1038/nprot.2008.73

27. Maciel KF, Brito LCN, Tavares WLF, Moreira Junior G, Nicoli JR, Vieira $L Q$ et al. Cytokine expression in response to root canal infection in gnotobiotic mice. Int Endod J. 2012 Apr;45(4):35462. https://doi.org/10.1111/j.1365-2591.2011.01983.x

28. Torabinejad M, Hong CU, Pitt Ford TR, Kettering JD. Antibacterial effects of some root end filling materials. J Endod. 1995 Aug;21(8):403-6. https://doi.org/10.1016/S0099-2399(06)80824-1

29. Oliveira MG, Xavier CB, Demarco FF, Pinheiro AL, Costa AT, Pozza DH. Comparative chemical study of MTA and Portland cements. Braz Dent J. 2007;18(1):3-7. https://doi.org/10.1590/S0103-64402007000100002 
30. Stessman HA, Bernier R, Eichler EE. A genotype-first approach to defining the subtypes of a complex disease. Cell. 2014 Feb;156(5):872-7. https://doi.org/10.1016/j.cell.2014.02.002

31. Braga JM, Oliveira RR, Martins RC, Vieira LQ, Ribeiro Sobrinho AP. Assessment of the cytotoxicity of a mineral trioxide aggregate-based sealer with respect to macrophage activity. Dent Traumatol. 2015 Oct;31(5):390-5. https://doi.org/10.1111/edt.12190

32. Pietschmann N, Rijntjes E, Hoeg A, Stoedter M, Schweizer U, Seemann $\mathrm{P}$ et al. Selenoprotein $\mathrm{P}$ is the essential selenium transporter for bones. Metallomics. 2014 May; 6(5):1043-9. https://doi.org/10.1039/C4MT00003J

33. Nair PN. Pathogenesis of apical periodontitis and the causes of endodontic failures. Crit Rev Oral Biol Med. 2004 Nov;15(6):348-81. https://doi.org/10.1177/154411130401500604

34. Zakharova M, Ziegler HK . Paradoxical antiinflammatory actions of TNF- $\alpha$ : Inhibition of IL-12 and IL-23 via TNF receptor 1 in macrophages and dendritic cells. J Immunol. 2005 Oct;175(8):5024-33. https://doi.org/10.4049/jimmunol.175.8.5024

35. Rezende TM, Vieira LQ, Ribeiro Sobrinho AP, Oliveira RR, Taubman MA, Kawai T. The influence of mineral trioxide aggregate on adaptive immune responses to endodontic pathogens in mice. J Endod. 2008 Sep;34(9):1066-71. https://doi.org/10.1016/i.joen.2008.06.006

36. Huang Z, Rose AH, Hoffmann PR. The role of selenium in inflammation and immunity: from molecular mechanisms to therapeutic opportunities. Antioxid Redox Signal. 2012 Apr;16(7):705-43. https://doi.org/10.1089/ars.2011.4145

37. Virtej A. Vascular endothelial growth factors and receptors: from normal dental pulp to apical pathology. [Dissertation]. University of Bergen, Helse Vest; 2016.

38. Montrucchio G, Lupia E, Battaglia E, Passerini G, Bussolino $F$, Emanuelli $G$ et al. Tumor necrosis factor alpha-induced angiogenesis depends on in situ platelet-activating factor biosynthesis. J Exp Med. 1994 Jul;180(1):377-82. https://doi.org/10.1084/jem.180.1.377

39. Sasaki H, Hou L, Belani A, Wang CY, Uchiyama T, Müller R et al. IL-10, but not IL-4, suppresses infection-stimulated bone resorption in vivo. J Immunol. 2000 Oct;165(7):3626-30. https://doi.org/10.4049/jimmunol.165.7.3626 PMID:11034365

40. Hahn CL, Liewehr FR. Update on the adaptive immune responses of the dental pulp. J Endod. 2007 Jul;33(7):773-81. https://doi.org/10.1016/i.joen.2007.01.002

41. Moon HJ, Ko WK, Han SW, Kim DS, Hwang YS, Park HK et al. Antioxidants, like coenzyme Q10, selenite, and curcumin, inhibited osteoclast differentiation by suppressing reactive oxygen species generation. Biochem Biophys Res Commun. 2012 Feb;418(2):247-53. https://doi.org/10.1016/i.bbrc.2012.01.005

42. Bellinger FP, Raman AV, Reeves MA, Berry MJ. Regulation and function of selenoproteins in human disease. Biochem J. 2009 Jul;422(1):11-22. https://doi.org/10.1042/BJ20090219 